\title{
FEASIBILITY USAGE OF NEW METHODS FOR OUTDOOR ADVERTISING AND URBAN SPACES WITH SUITABLE LOCATING OF GORILLA TECHNIQUE (CASE STREET SAFAZANJAN)
}

\author{
Mahdi Sashourpour \\ Islamic Azad University, Zanjan,IRAN \\ mahdisashourpour@gmail.com \\ Mohammad Heidari \\ Islamic Azad University, Zanjan, IRAN \\ mohammadheidari.urban@gmail.com
}

\begin{abstract}
Our social environment is full of differentdata and visual elements, Some with planningand planned out the clear origin information, others without considering the specific target population. However aesthetics as a branch of philosophy concerned with the nature, beauty and esthetic perception, we will help in the realization organize this chaotic environment. Perhaps the Gorilla, the aesthetic is meant to research on the nature of sensory perception and, in principle, perceptual and sensory aspect is the concept of aesthetics. Since today's advertising and information are associated with large amounts of data, understanding norms helps us with contacts (the target) has placed a faster connection and data codes to optimally transfer. As a result, nowadays we want to achieveaVisual line, has changed compared to the past and breadth of our vision, to the sky, gradually through the buildings become limited. Nature around us,not only visually, but also in terms of alter auditory and visual elements called outdoor advertising also added to the building. Undoubtedly, if between these elements, Logical relations and organized placed, will doubleadverse environmental effects. Therefore, the above changes, meaning the society of normal and abnormal conditions, such as worry, anxiety and fear in the people. And reducing the amount of natural conditions of peoplelife, it will lead to a stressful life. And Gorilla is one way to reduce stress to create peace and order.
\end{abstract}

Keywords: visual elements, aesthetics, Gorilla, target population, outdoor advertising

\section{DIŞ REKLAM VE GORILLA TEKNİĞININ UYGUN KONUMU ÍLE KENTSEL ALANLAR İÇIN YENİ YÖNTEMLER VE FİZIBİLITE KULLANIMI (OLGU SOKAK SAFAZANJAN)}

ÖZ

Bizim sosyal çevre özel hedef nüfusu dikkate alınmadan differentdata ve görsel öğelerin, Bazı planningand net kökenli bilgi planlı, başkalarının doludur. Ancak doğa, güzellik ve estetik algı ile ilgili bir felsefe dalı olarak estetik, biz bu kaotik ortamı düzenlemek gerçekleştirilmesinde yardımcı olacaktır. Belki Gorilla, estetik prensipte duyusal algı doğası ve üzerinde araştırma içindir, algısal ve duyusal yönü estetik bir kavramdır. Bugünün reklam ve bilgilendirme, büyük miktarda veri ile ilişkili beri normları anlamak kişileri (hedef) ile bize yardımcı olur en iyi şekilde aktarmak için daha hızlı bir bağlantı ve veri kodlarını vermiştir. Sonuç olarak, günümüzde biz achieveaVisual hattına, binalar sınırlı hale yavaş yavaş aracılığıyla, gökyüzüne, vizyonumuzun geçmiş ve genişliği ile karşılaştırıldığında değişti istiyorum. Çevremizdeki Doğa değil, sadece görsel değil, aynı zamanda açık hava reklam denilen alter işitsel ve görsel öğeler bakımından da binaya ekledi. Kuşkusuz, bu elemanların, Mantıksal ilişkiler ve organize 
yerleştirilir, doubleadverse edecek çevresel etkiler arasında ise. Bu nedenle, bu tür insanlar endişe, kayg1 ve korku gibi normal ve anormal şartlarda, toplumu anlam yukarıdaki değişiklikler. Ve peoplelife doğal şartlarda miktarını azaltarak, bu stresli yaşam yol açacaktır. Ve Gorilla barışı ve düzeni oluşturmak ve stresi azaltmak için tek yoldur.

Anahtar kelimeler: görsel öğeleri, estetik, Gorilla, hedef kitle, açık hava reklam

\section{INTRODUCTION}

Oneindicators of urban and the cultural level of society, advertising environment . In the beginning, the main goal of informing citizen and beganfrom head of shops and stores, but gradually turned into a media giant and powerful. In Iran, outdoor advertising related to trade and production that began with contacts. Today in the business world, everything, including promotional activities and ideas are changed and different. Aimless repetition of past patterns implemented in the audience will only boredom and increase the costs will not be inconclusive. Gorilla provider hasnew approaches to avoid the problem. In other word, this style of promotional activities based on reducing costs while increasing the attraction, retention and effectiveness advertising messages in the minds of buyers and consumers (target group) takes place. Select the Gorilla word reminiscent of a sudden operation, which will have the greatest impact in the shortest time, because this form of marketing activities confidential manner, eccentric and full of creativity in the most suitable position, time and place, will beinfluence into the hearts and minds of the audience. This is a new style of advertising for several years in many developed countries implement and design.On this basis it is trying to introduce the basic principles and techniques of advertising with Gorilla, provide the best samples in the industry and numerous countries with the easiest way to explain the techniques and ideas effectively with regard to culture, lifestyle and unique behaviors of employedpeople.

\section{DEFINITIONS AND CONCEPTS WHAT ISADVERTISMENT?}

Convey the messageor story to people, communicated or issue a news release with the help of various means of advertising (radio, TV, outdoor advertising, newspapers, etc.) to people, covering public opinion, informing the formal and informalcitizens. In this kind of awareness, education does not work and the audience in the process of looking for tutorial but also (advertisers) who go to him. (Ahmad GiviVanvry, 1995)

Advertising (advertising) have an educational value, but the same is not Advertise education, work training, promotion and development of cultural, social, political and religious. (Ahmad GiviVanvry, 1998)

People advertising in the field of economic, social, political, religious, civil rights and the search and alert . Of course, if it is true. Create the effect of advertising on the "message", "signaling" and "recipients" or contact and relations between these elements. (Whiston, 2005)

\section{OBJECTIVESADVERTISING:}

Apprisethe audience, convincing the audience, reminding the audience, increasing the number of contacts in economic, social, political, civil rights, religious and cultural interest of the institution, organization and... are general objectiveadvertising. (A.d.farby, 2007)

\section{DEFINITION OF OUTDOOR ADVERTISING:}

All advertising and informing in outside (Out door) that is happening outside of the interior spaces and outdoor advertising, call outdoor advertising

\section{THE VISION AND ULTIMATE GOAL OF THIS RESEARCH IS:}

** Restore organizing, create and accentuate the purpose of advertising and persuade the audience to what we want.

Due to the influence of advertising, classical media like radio, TV, billboards, and ... want to take advantage of the technology used leading countries in this important and influential industry using three principle messaging, media selection and createmedia who have no limiting rules and conditions for expressing ideas puzzling benefit from each and every vehicle into the media' Reverse marketing at a 
time when traditional media noise and repeatedly are futile 'Gorilla audience to make noise and they are in situations that become part of the media and creative alternatives to be repeated.

"The roadmap of this research is finding ways to communicate with audiences and encourage and strengthen them."

\section{Table 1-1: Types of advertising tools}

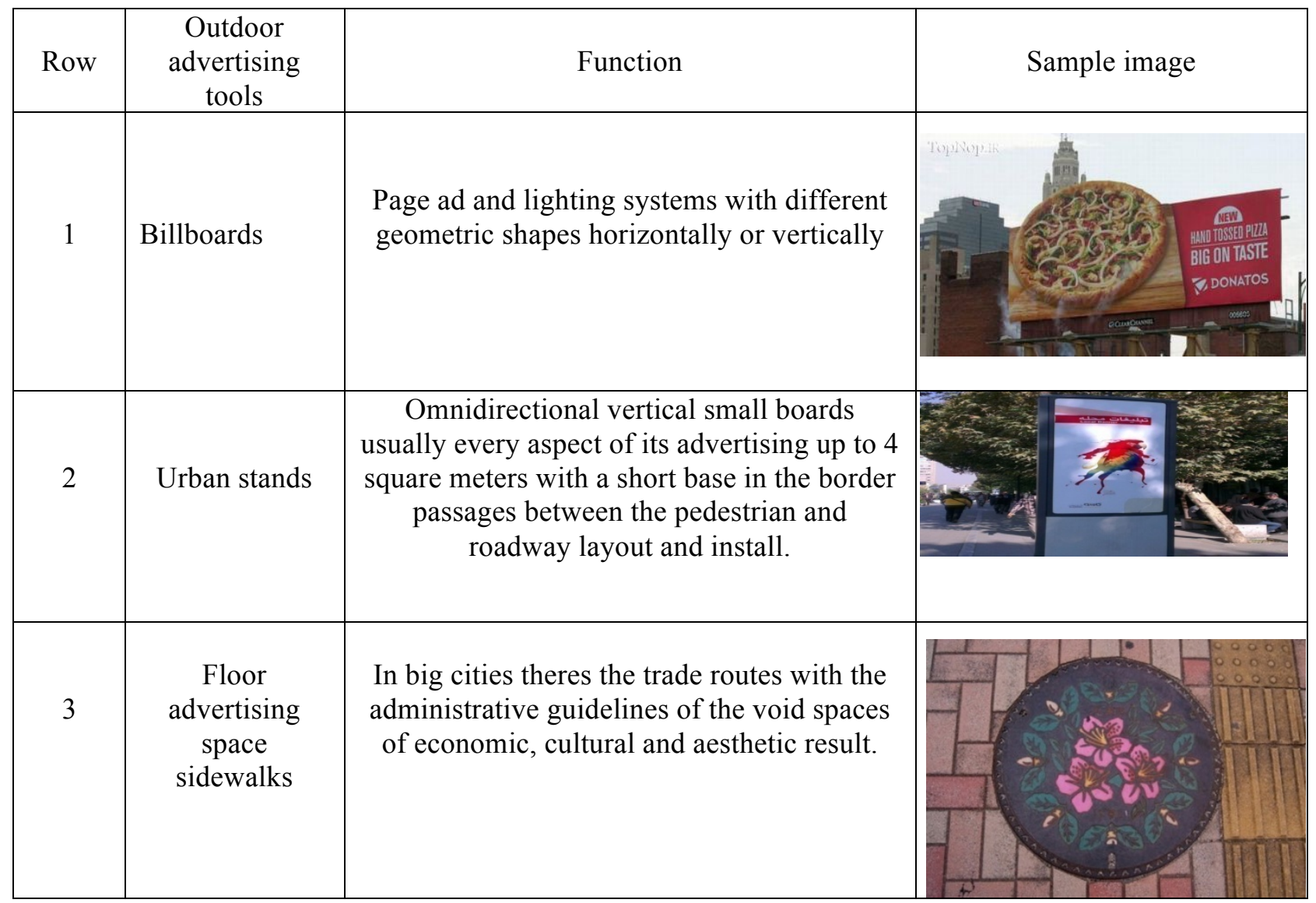

Table 1-2: Classification of environmental advertising tools

\begin{tabular}{|c|c|c|}
\hline Row & $\begin{array}{c}\text { Types of outdoor } \\
\text { advertising }\end{array}$ & Sub-classification \\
\hline 1 & $\begin{array}{c}\text { Traditional outdoor } \\
\text { advertising }\end{array}$ & $\begin{array}{r}\text { The Sound of tourists, graffiti, writing hills, street decoration, } \\
\text { labeling on the walls }\end{array}$ \\
\hline 2 & Advertising outside house & $\begin{array}{c}\text { Asked posters urban, pedestrian bridges and roadway, city } \\
\text { stands, advertising walled city and ... }\end{array}$ \\
\hline 3 & Urban furniture & $\begin{array}{c}\text { Urban seats, dustbins, kiosks, urban, urban stairs, urban facility } \\
\text { and ... }\end{array}$ \\
\hline 4 & Advertising pass & $\begin{array}{c}\text { Advertising inside and outside vehicles such as buses, trucks, } \\
\text { subway, advertising billboards Mobile }\end{array}$ \\
\hline 5 & Trademarks & Shopping centers, transport terminals, etc. \\
\hline 6 & Advertising on air & $\begin{array}{r}\text { Banners and air balloons, sky conventional programming, } \\
\text { advertising balloons }\end{array}$ \\
\hline 7 & Electronic advertising & $\begin{array}{c}\text { Digital outdoor advertising, television urban and park, laser show } \\
\text { and Mental boards and LCD LED night lighting }\end{array}$ \\
\hline
\end{tabular}




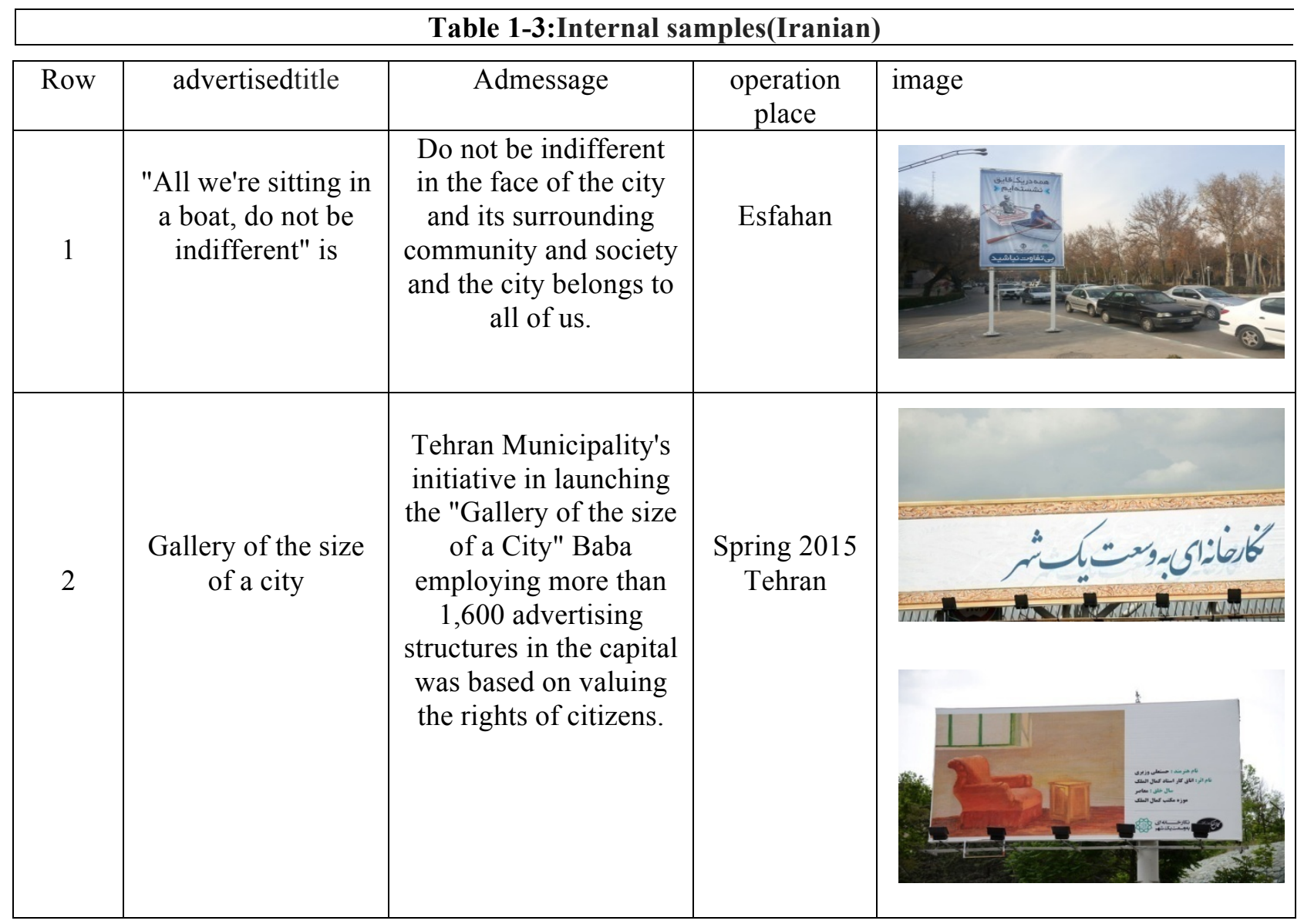

Source Writer

\section{Table 1-4: Examples of Universal (non-Iranian)}

\begin{tabular}{|c|c|c|c|c|}
\hline Row & As advertised & Message Ad & $\begin{array}{c}\text { operation } \\
\text { place }\end{array}$ & image \\
\hline 1 & $\begin{array}{c}\text { Don't step } \\
\text { into danger(You } \\
\text { do not walk into } \\
\text { danger) }\end{array}$ & $\begin{array}{c}\text { Here is the order of } \\
\text { the risk of streets and } \\
\text { sidewalks safe for } \\
\text { pedestrians and } \\
\text { pedestrians from the } \\
\text { streets is important. } \\
70 \% \text { of accidents for } \\
\text { pedestrians crossing } \\
\text { the street instead of } \\
\text { the sidewalk }\end{array}$ & $\begin{array}{c}\text { Auckland } \\
\text { Christensen }\end{array}$ \\
& & & \\
\hline
\end{tabular}




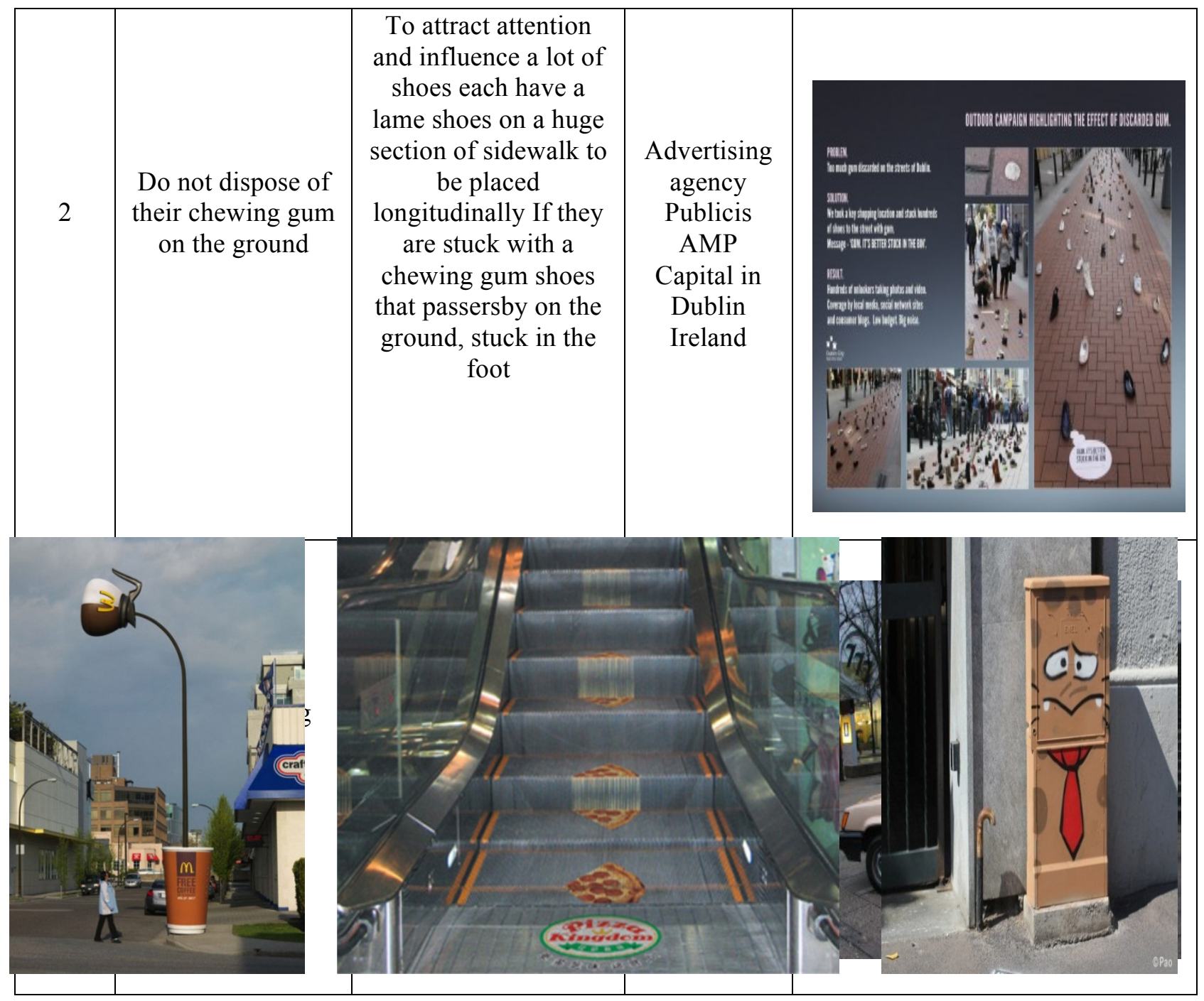

\section{A COMPARISON OF THE OUTDOOR ADVERTISING WITH OTHER ADVERTISING OPTIONS}

Unlike TV, radio or print advertising media environment that can not be switched off or be terminated. While visitors can pass by an outdoor advertising or Login to see the range of strategically embedded which display (such as billboards) reject them. In the case of television, radio, print and the Internet, consumers have the option to change the channel, the ad will reject, reject that page (or eliminate) or close the browser window.

In environmental advertising consumers do not have control of advertising spaces. This gives advertisers the power of how and where showone ad. Outdoor advertising gives advertisers more control over their advertising space, while other advertising media to advertisers provide less control.

Source Writer

\section{Image $1-1$}

Billboards advertis in the media environment is one of the best tools in the undeniable power companies to introduce products and services and cultural affairs. Billboards with specific forms and ideas make the viewer to think about the attitudes, aims and object of those ideas that bring the designers and owners of goods and services to the ultimate goal, more sales and more favorable transparency. With human progress and new technologies are occasionally witnessed the arrival of new tools for outdoor advertising Including urban and drawings of three-dimensional television giant that is acquired twenty-first century. 


\section{RESEARCH METHODOLOGY:}

Including assessment, feasibility study and environmental infrastructure in order to advertising Gorillatechnique

\section{ADVERTISING PROJECT EVALUATION:}

Several studies conducted to evaluate advertising and a variety of methods and tools in hand.

Study and research advertising in kind of research such economic, social, cultural and political. The ads may be associated with one of these categories. Therefore, it is necessary to develop faith-based budgeting annual economic propaganda organ, institution, corporation, political, social and cultural institutions, along with the promotional item advertising budget must be considered.

\section{REVIEWS}

In any position of advertising, outdoor advertising should expect with the role that advertising and marketing plays in the overall strategy, started. The purpose of making contacts and creating a mental picture to the public and to contribute to the success of advertising plays an important step. Industry advertising allows us a way that was never possible, carefully targeting your audience and improve the image of outdoor advertising to the general public. And for this we need to find ways to adapt and find a compromise with environmentalists and others have a responsibility towards society and must be fixed.

\section{FEASIBILITY}

Preparing, distributing and collecting questionnaires to identify and interests of workers, residents and passersby to create a variety of attractions and infrastructure categories and to update the study area, Czech producers listed deficiencies, deficiencies, needs, capabilities and features to create a platform the right to organize, refine and outdoor advertising design ideal for the culture of the target range. So identify the main purpose of the route, to achieve the ideal result in ads. And evaluation of possible projects advertising and promotional better the strengths and weaknesses of a occurproject.

It is no secret the importance of advertising as well as social factor, play a significant role in changing attitudes and behavior and habits of institutionalized society. This has led to cultural institutions, social and business spend large amounts of their income advertise. Here is what can make the difference, different ways of advertising that each of the institutions chosen for their particular way. The role of the physical environment of the city in educating citizens is very complex, so to get an education, raise awareness of citizens to rights and obligations of citizenship, participation in the performance of urban management missions, religious education and the dissemination of national themes of ethics and citizenship, health promotion environments is friendly. Ultimate goal of environmental education, creating every citizen is responsible perspectives.

\section{QUESTIONNAIRE:}

Poll about advertising attractions, needs and deficiencies Street Safa in the form of questionnaires from residents, businesses, municipal authorities and asked passers-by and the views of citizens in the form of a questionnaire, taken from the 100 resident and just charts were prepared.

\section{QUESTIONNAIRE}

- Are you satisfied withthe promotional items available?

$\square$ Yes $\square$ No

- What is your reasons for satisfaction or dissatisfaction with the status quo ads?

$\square$ Have been sufficient $\square$ Are not sufficient $\square$ According to your taste and need

$\square$ Does not secure your taste and need

- How is your consider priorities in check and see pictures?

$\square$ Commercial signs $\square$ Cultural Boards $\square$ Plank Trail Guide $\square$ Social Bookmarks stands

- What type of signboards advertising you feel need more?

$\square$ Cultural and social $\square$ Trade, businesses and unions $\square$ National and religious $\square$ None

- Is advertising in the citysuseful to promotcultural and social culture?

口Yes $\square$ No

- Is advertising in Safa Street efficient and attractive?

口Yes $\square$ No

- In your opinion does Safa street outdoor advertising need to change, upgrading and modernizing? 
$\square$ Yes $\square$ No

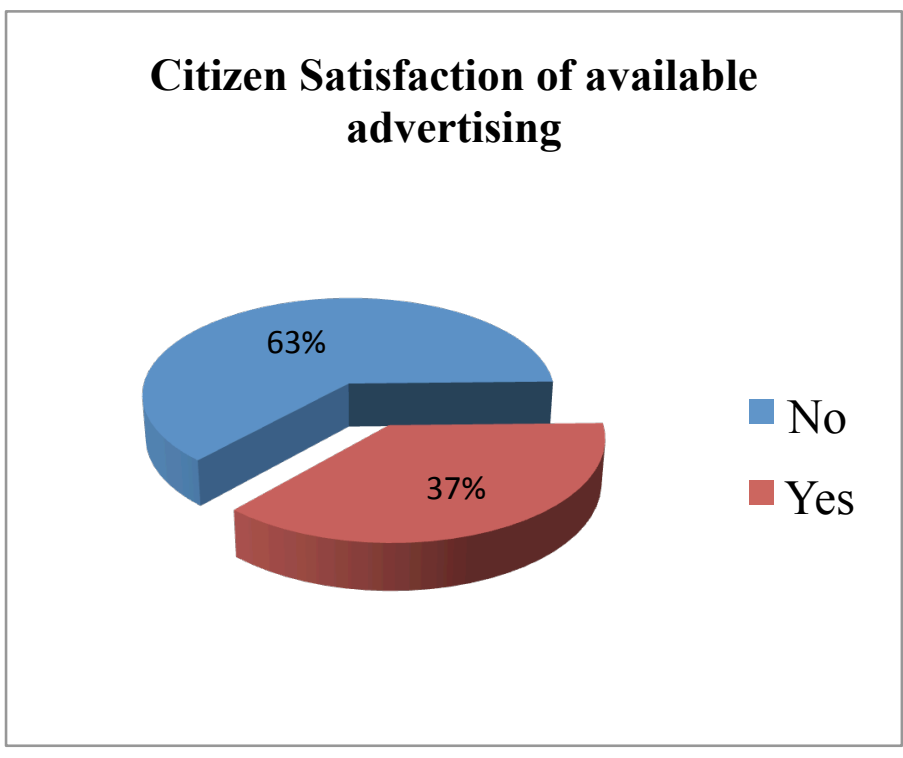

\section{The satisfaction or non-satisfaction of the status quo}

categories and items, do you think is necessary?

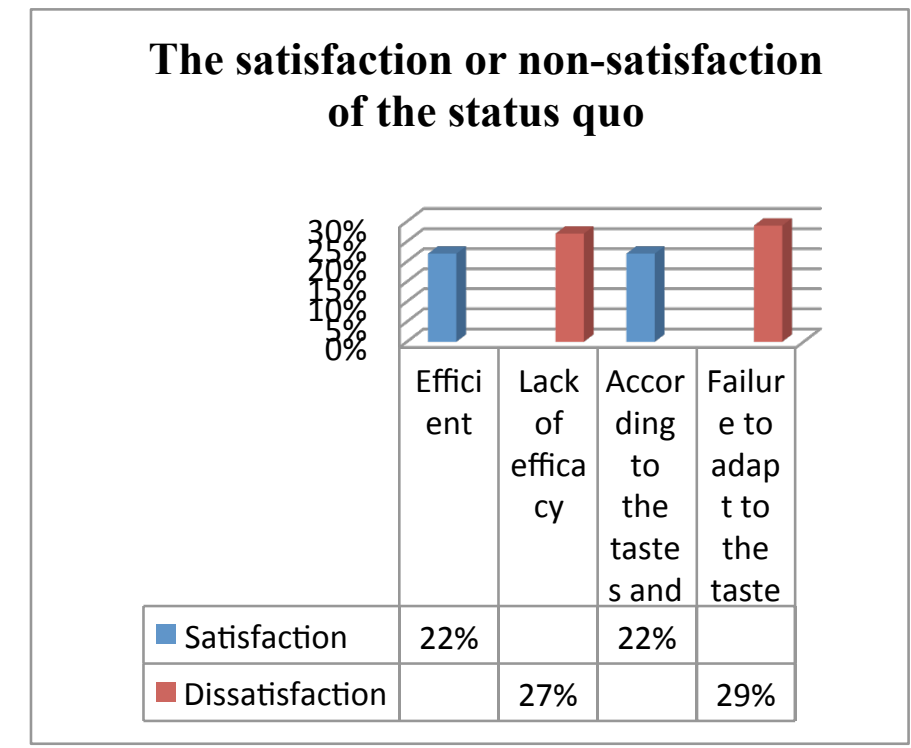

- Outdoor advertising of Safa Street in which

$\square$ Traffic Units and services $\square$ Banks and financial institutions $\square$ Governmental and quasi-governmental institutions and agencies-Educational and Cultural Affairs $\square$ Religious Affairs and National Traditional $\square$ Citizenship education and socialDUrban is sues and aesthetic

\section{The priority in the review and see pictures}

$\square$ Commercial Directions

- Cultural Social Bookmark
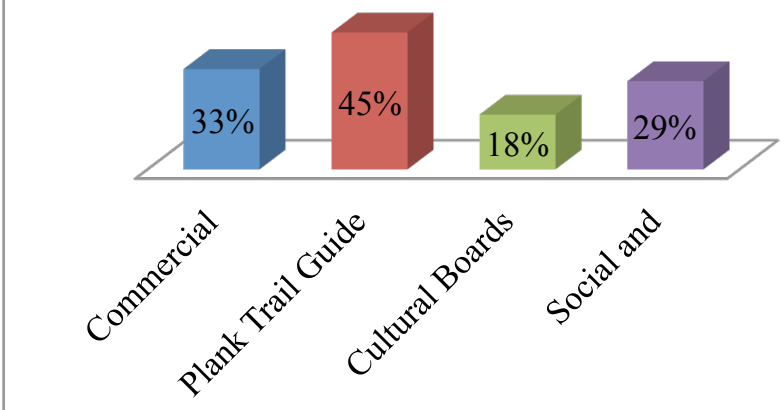

\section{RESULTS EXTRACTED FROM THE}

$\begin{array}{llllllllllllll}\mathbf{Q} & \mathbf{U} & \mathbf{E} & \mathbf{S} & \mathbf{T} & \mathbf{I} & \mathbf{O} & \mathbf{N} & \mathbf{N} & \mathbf{A} & \mathbf{I} & \mathbf{R} & \mathbf{E} & \mathbf{S}\end{array}$ The overall results of the survey and questionnaire output in graph format is followsas:

\section{The citizens need to ads type}

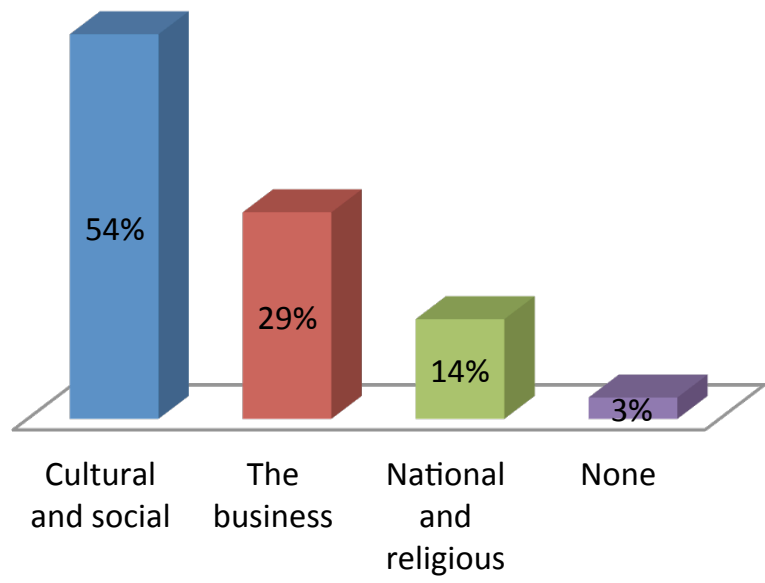

Figure 2-1: (Source author)

Figure 2-3: (Source author)
Figure 2-2: (Source author)

Figure 2-4: (Source author) 


\section{Is advertising in the city to promote cultural and social culture useful?}

No $\square$ Yes

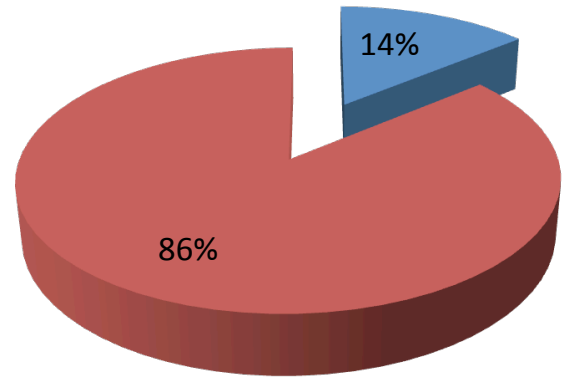

Figure 2-5: (Source author)

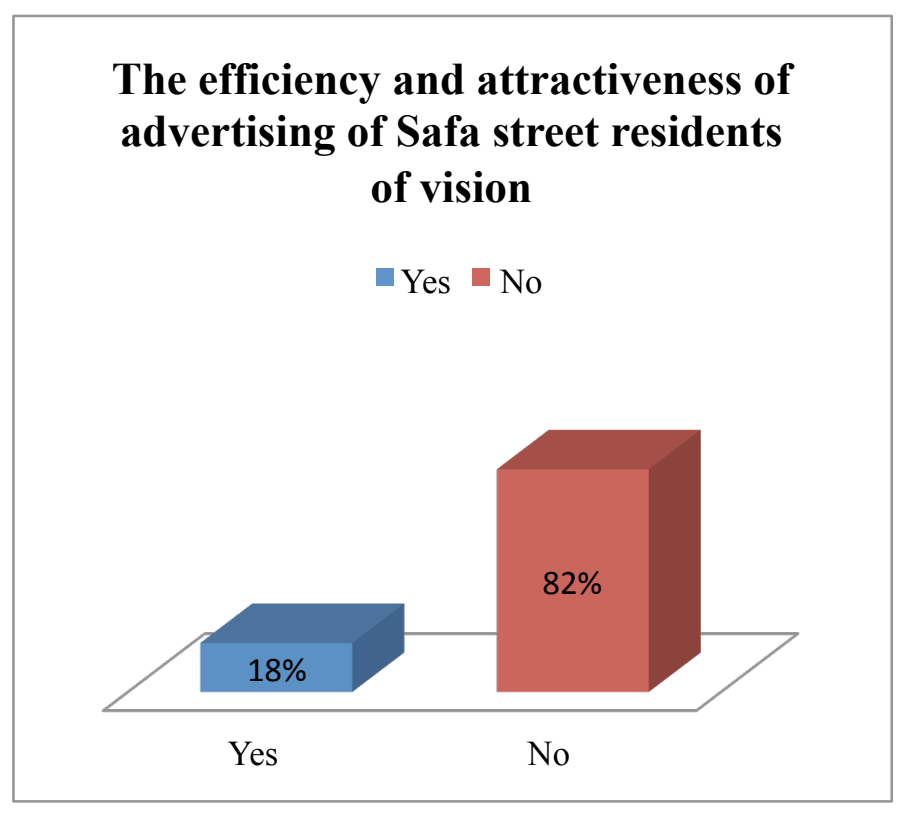

Figure 2-6: (Source author)

Figure 2-7: (Source author)

Figure 2-8: (Source author)

CONCLUSIONS BASED ON OUTPUT OF THE QUESTIONNAIRE:

The interest of citizens to change, reform and modernization of outdoor advertising in the safa street

No Yes

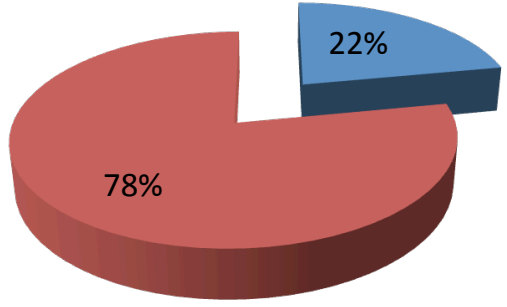

\section{Required citizens to what is more} essential than outdoor advertising in Safa Street
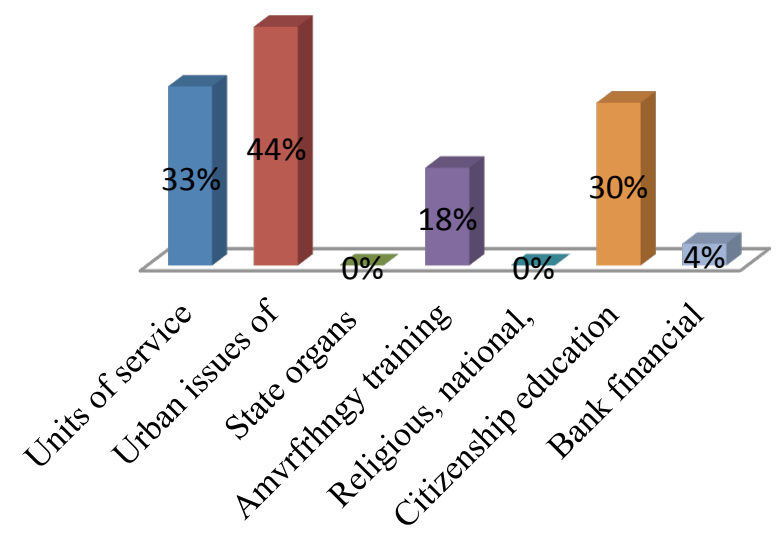

Overall outcome of this research field through surveys (questionnaire) is as follows:

- More residents and citizens need to change and modernization with modern and creative way (Gorilla) fully observed.

- Change the priorities of the cultural and social issues, also focuses urban culture.

- Social Urban Affairs and the opinion of citizens with outdoor advertising targeted to be institutionalized.

- Beauty and vitality of the city is most important to them.

- And finally of promotional items available unhappy and do not know them according to your tastes and needs. And changes in all directions, and they are required to change your priorities on social affairs and 
urban culture are possible And creative advertising designed to promote law and order full color city know And outdoor advertising creative and modern culture based on social interactions and better urban environment in which they occur, welcome.

\section{FEASIBILITY STUDY:}

according to the interests and needs of citizens in a usability study to prepare the Czech list of urban facilities and infrastructure was expected range, according to multiple intersections are also training centers and health and historical, and based on consultation with the Department of advertising design collaboration environment (including psychologists, sociologists, communication experts, urban design engineer, architect, expert graphics and advertising expert) the best way Gzynh implement interactive design, social, attractive and work came (from Azbagh Iran) is. In the environmental review and feasibility study area there is the best possible for the idea and can make the most of this was possible.

Zanjan, a city in the North West of Iran, the province and the city a center of religious and influential in the history of Iran.

Safa Street (working) on the north side of the old city of Zanjan is located, not far from the boulevard Chamran, Landmark matches the streets of Zanjan factory, which is located on the east side of the street Safa and every day a lot of Znjanyha watch this massive building and sometimes elderly people remember the quote. People with the Plant Zanjan in Zanjan lived and many people are working on it for the first time And memories of ordinary people big and small, black and Zanjan purity of the plant still remains in the minds and persistent. Sustainable and efficient use of space in front of the factory matches for designing an interactive walk can be derived from the creativity Gorilla Engage citizens in various sections are the best Gzynh, the use of creativity that matches the culture Gorilla interests citizens.

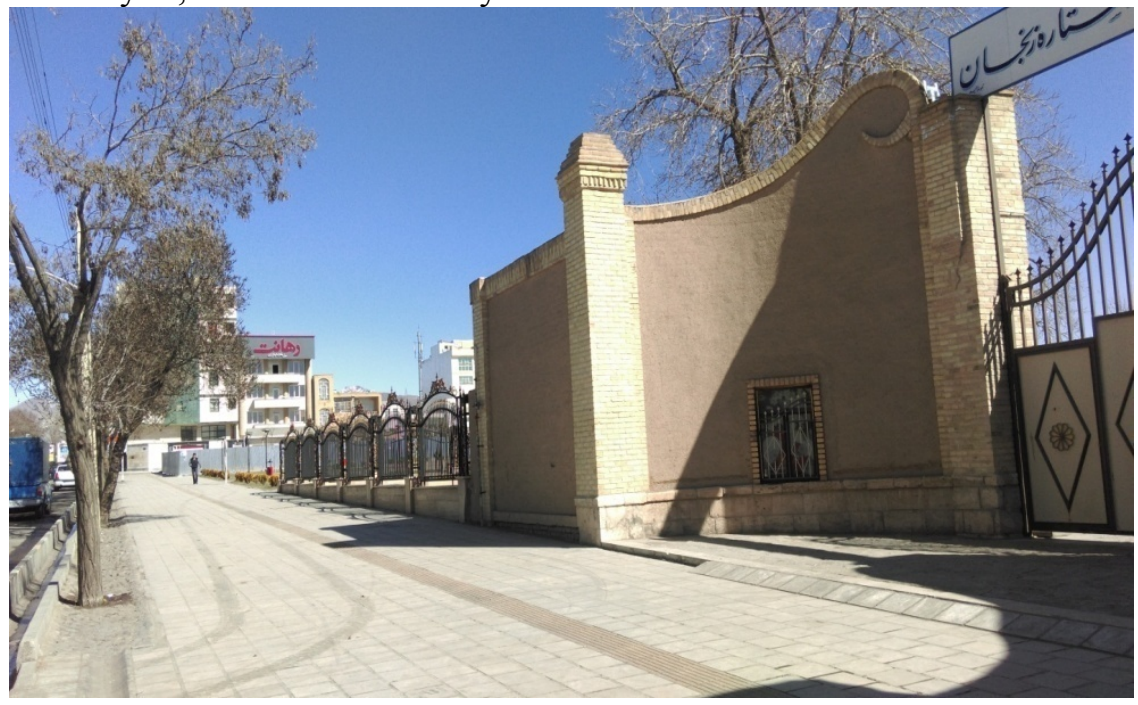

Image 1-2 (selected area of the factory Zanjan matches) 


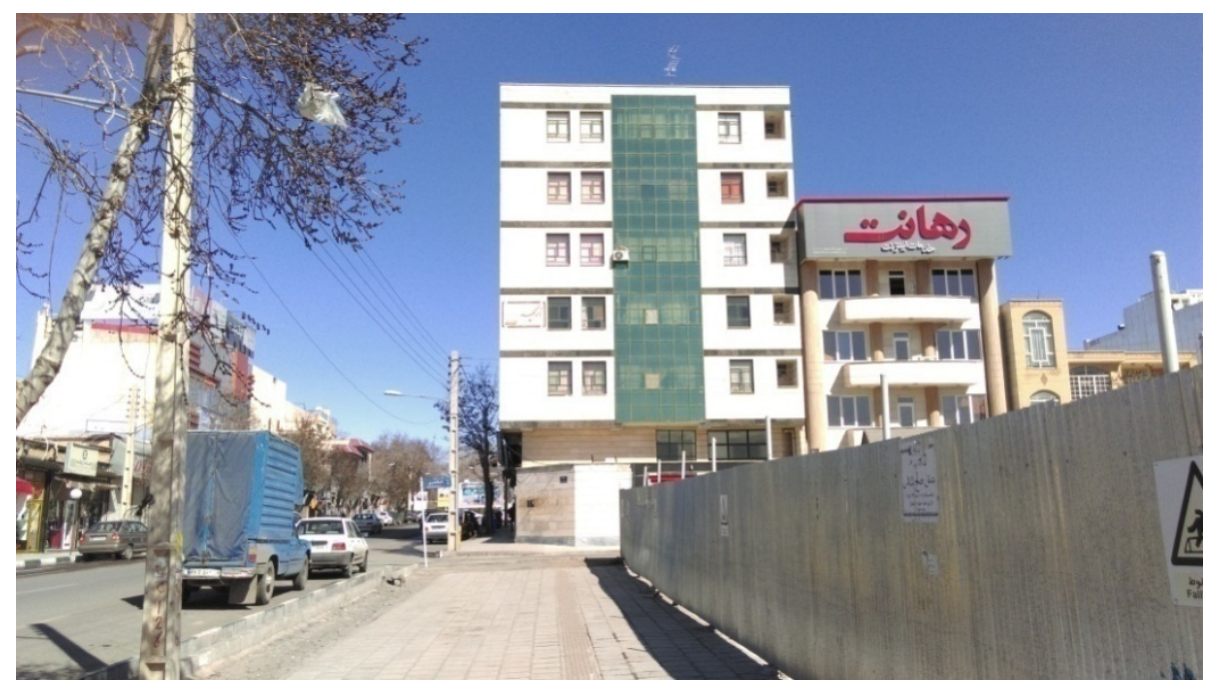

Pictures 2-2 (selected area ofMatches factory of Zanjan)

\section{CHOOSE AN INDEX BUILDING TO IMPROVE DESIGNING OF SIDE WALK WITH GORILLA TECHNIQUES:}

Select anindex building for environmental basis for the promotion of technical properties, applications and creativity is Gorilla Most of it is used to attempt to teach cultural and social norms and have the ability to change different time gates. The project is important to the success and recognition. Construction orchids in the street of fun at the proper height and its location relative in the Safa street, Dimensional spatial and aesthetic graphics used for the outdoor advertising with culturally appropriate services.

\section{DESIGN}

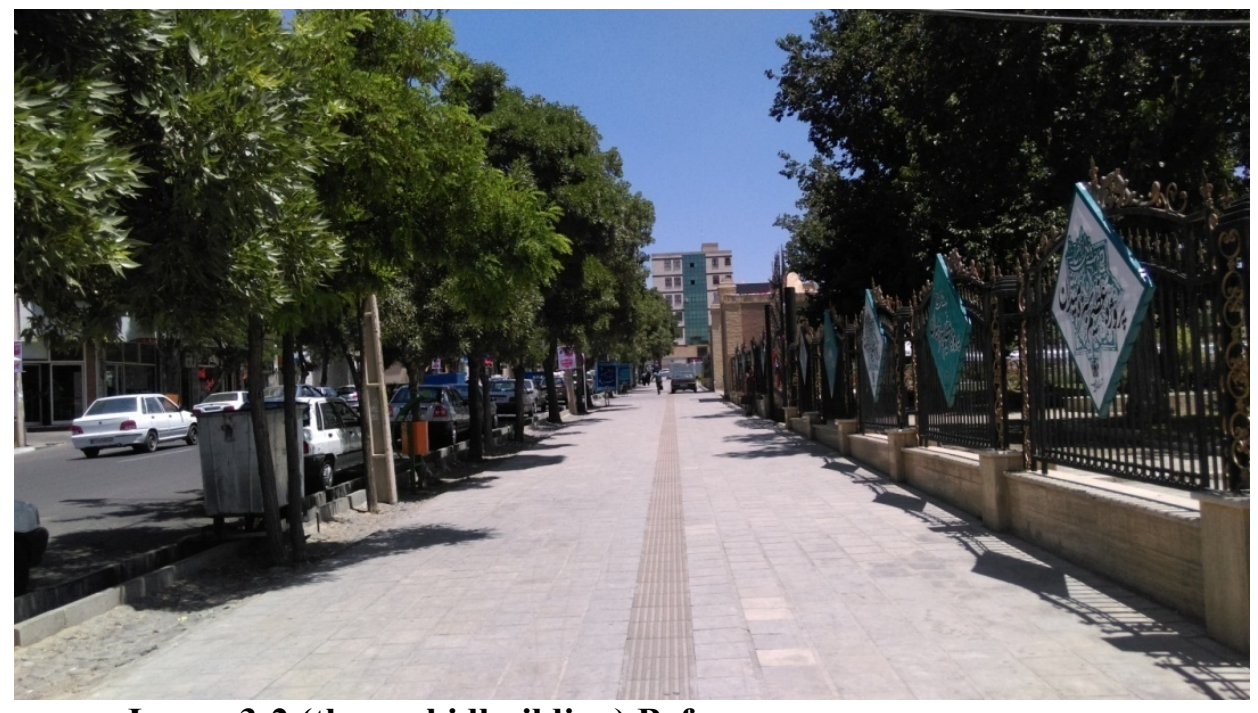

Image 3-2 (the orchidbuilding) Before

That according to a side walk taken from the architectural design to create a Persian garden (which in this case is considered Fin Garden in Kashan) to encourage citizens to use the sidewalks Also observe the municipal culture and history and memory mechanism is designed spaces, interesting for use in the design, cleanliness, tranquility and make-up environment is considered., Which is a socio-cultural advertising, along with the building of orchids index that is intended to be advertising balloons, Laser show and even fountains of interest be appropriate. 


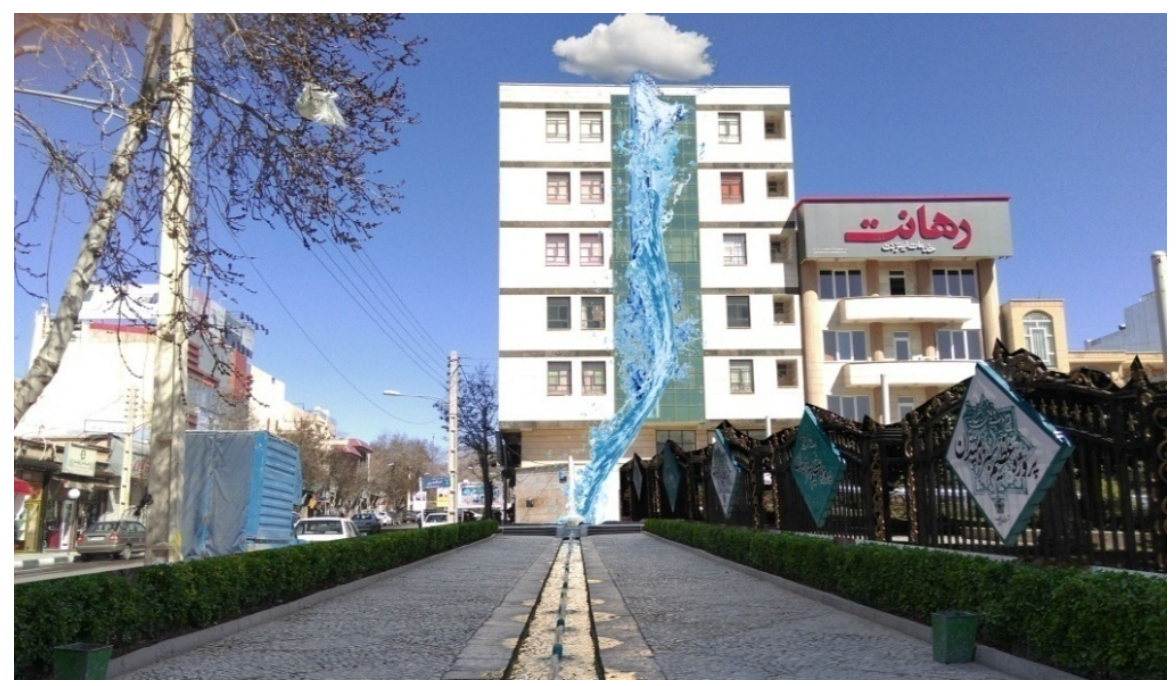

Image 1-3 (index and of design orchidbuilding) After

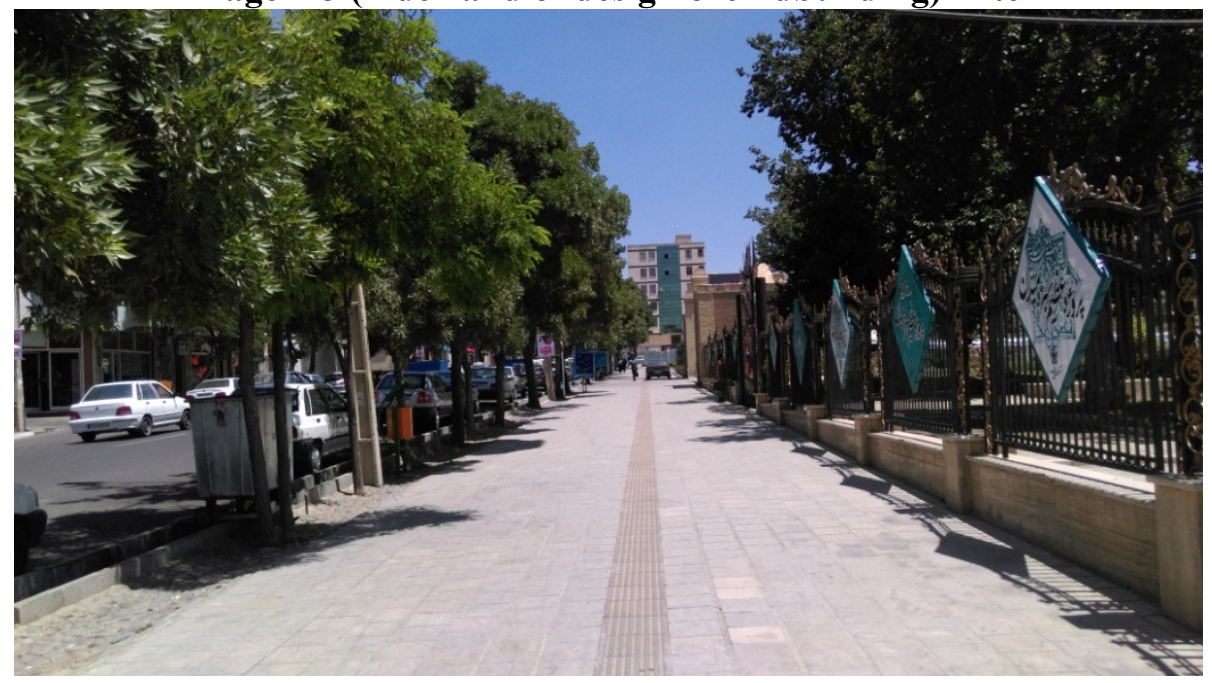

Image 2-3 (sidewalk, against the matches of Zanjan) Before

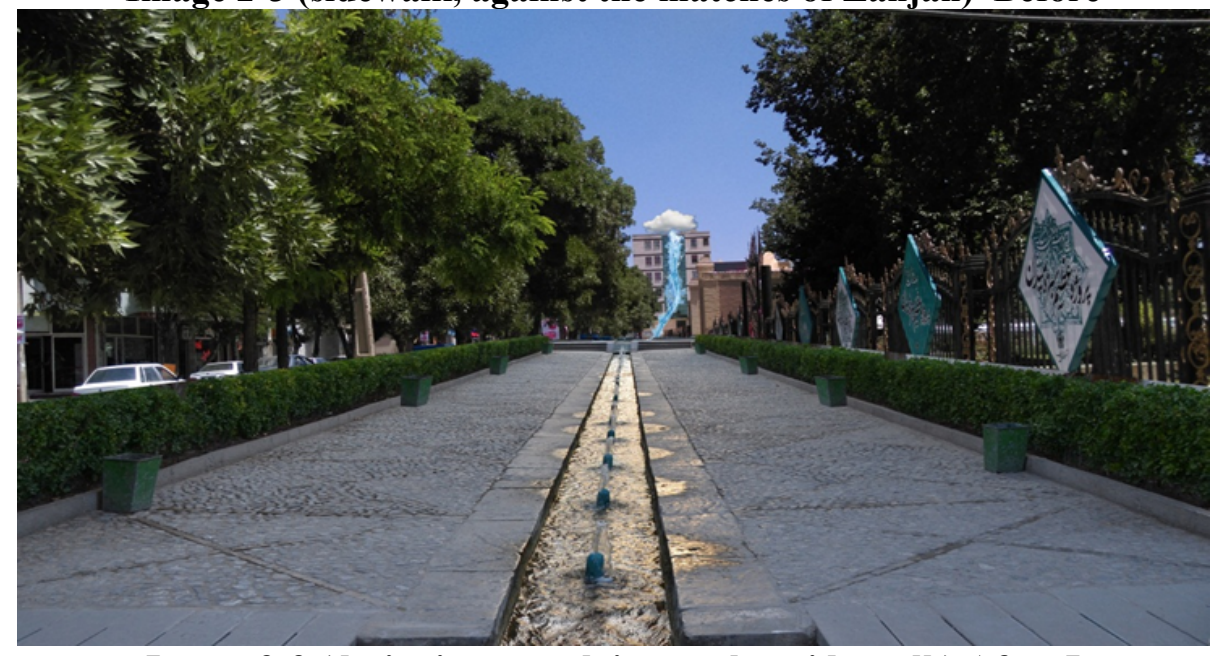

Image 3-3 (designing nostalgic matches side walk) After-I 


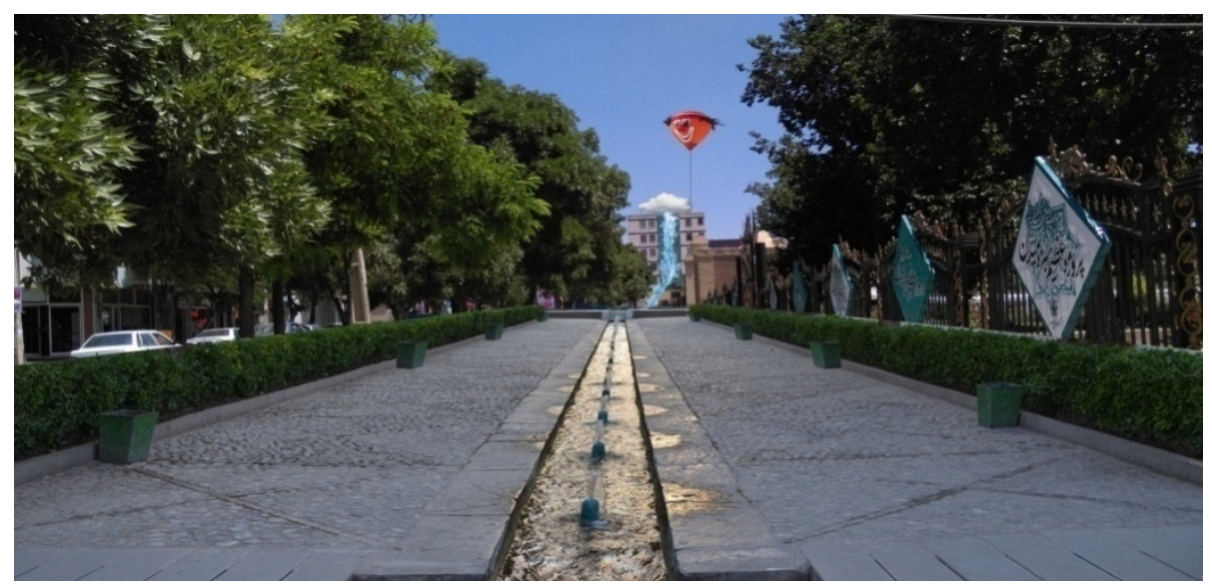

After-II

Image 4-3 (designing nostalgic matchesside walkadvertising balloons)

\section{TOTAL RESULTING OF RESEARCH:}

Outdoor advertising phenomenon because profitability and the audience to one of the fastest growing business areas, Social and Cultural Rights has become so accelerated the process of creating visual chaos in urban environments and become fast. As a result, the organization and regulation must be continued the definition and characteristics of aesthetic desirability of the city and finally brought upon the consent of the people.

Examine the experiences of specialists, planners and managers of other countries shows, communities have only limited success in this area that, firstly for the status quo and regulations have developed a dynamic and fluid that opens the door to establish order in the city. And secondly, general strategy and guidelines that can be created and the account of the phenomenon of urban and modern issues and the order to act during their utility .

Thus, all companies are competent to, organizations and individuals concerned with environmental advertising, to meet the criteria and rules to regulate the status quo action and beautify the urban environment through respect for the law and provide convenient and innovative ways to contribute.

\section{REFRENCES}

1. Ahmad/Taghi-2008-engineering terminology dictionary - sighted over green - Second Edition

2. It Whiston / Aspyrn - 2005 landscape language translators and Bhnaz amynzade born Syed Hussain Bahraini - Tehran University, Second Edition

3. A.D / Farabi - 2007- How to build a successful advertising - Translator Golchinfar and Amir Bkhtayy Publishing Industrial Management Institute

4. Al / Jack Trout -2013 - positioning (Battle in mind) - the translation of the Tarane ghotb - Tehran, spasticity - Second Edition 2013

5. Professor Chowdhury / Arjaan - 2012- emotion and logic in consumer behavior - translations doctor K. Heidarzadeh - Tehran, Sithe

6. Ghafuri / Shahbaz -2012- urban morphology propaganda in Tehran - Dybayh - Printing

7. Sadre Mohammadi / AR -2010 - why outdoor advertising - Tehran, Sithe - Second Edition

8. Beautification Organization / in Tehran -2012 - especially in a city, life, beauty (outdoor advertising) Department of Planning and Development

9. Mohamadian / Mahmoud - 2012 - Advertising Management - adherents - Sixth Edition

10. Studies Center Beautification Organization / entitled - 2011 - Recipes plate design lamps and indicator boards - October

Articles :

Beautification Organization / Tehran - the vibrant streets - translator Hamid Reza Hajizadeh and N. Mohammed Gholizdeh - National Library of Tehran - Twelve 1392- 


\section{List of non-Persian sources}

1. Martha, Cill, 2000, Color Harmony Pastels, United States of America. PP.27-60.

2. Forster, Ania\&Peter Kreuz , 2012 , Alles auber gewohnlich(German), Econ. pp 10-14.

3. Patalas, Thomas, 2012 , Guerilla Marketing(German).pp8-70.

4. Schuite, Thorsten, 2010 , Guerilla Advertising(German), verlag Wissenschaft and Praxis. 